\title{
What Trump's China Tariffs Have Cost U.S. Companies?
}

\author{
Refk Selmi ${ }^{1+}$, Youssef Errami1 ${ }^{1}$, and Mark E. Wohar ${ }^{2,3}$ \\ ${ }^{1}$ ESC Pau Business School, France \\ ${ }^{2}$ University of Nebraska at Omaha, USA \\ ${ }^{3}$ Loughborough University, UK
}

\begin{abstract}
For decades, the two economic superpowers - the U.S and China-have converged on seemingly contentious issues. However, the U.S. administration under Donald Trump's presidency is now attempting to undo that as a deepening trade rift with China affects businesses in both economies. In July, August, and September 2018, the United States successively increased tariffs on a total of $\$ 250$ billion in annual imports of Chinese goods, stating that it wished to safeguard U.S. companies from unfair Chinese practices and reduce the bilateral trade deficit. China responded with tariffs on $\$ 110$ billion of imports from the United States. The trade tensions between the two economic superpowers have led to a significant and rapid reduction in bilateral trade in taxed goods. Our study employed an event study methodology to investigate the reactions of the sectoral U.S. stock prices to the China tariffs. This paper seeks to examine the heightened uncertainty surrounding the U.S.-China trade war to shed some light on the reactions of sectoral U.S. stock market to China tariff threats. Generally, the initial effects of trade tensions appear more significant than had been expected, reflecting the uncertainty shock. Specifically, the responses of information technology, industrials, and energy were even more severe than the reactions of financials, consumer discretionary items and staples, healthcare, real estate, aerospace and defense, and utilities. Designed to create a portfolio with balanced exposure, certain sectors have been positioned for offense (information technology and industrials) with others for defense (healthcare, real estate, and utilities). Our results clearly show that the sentiment and confidence of investors are impacted by heightened uncertainty.
\end{abstract}

Keywords: US-China Trade War, Tariffs, U.S. Stock Market, Sectoral Level Analysis

JEL Classifications: G11, G13, G14, G15

Received 13 November 2019, Revised 17 February 2020, Accepted 4 March 2020

\section{Introduction}

The election of Donald Trump as U.S. president generated an era of heightened uncertainty for an already vulnerable world economy. Figure A1 (Appendix) displays the economic policy

\footnotetext{
+Corresponding Author: Refk Selmi

Associate Professor of Finance and Big data, ESC Pau Business School, France, Email: refk.selmi@esc-pau.fr Co-Author: Youssef Errami

Professor of Management, ESC Pau Business School, France, Email: youssef.errami@escpau.fr

Co-Author: Mark E. Wohar

Distinguished Professor of Economics, College of Business Administration, University of Nebraska at Omaha, USA;

Visiting Professor of Internationa Finance, School of Business and Economics, Loughborough University, UK,

Email: mwohar@unomaha.edu
} 
uncertainty index for the USA. This has fluctuated widely since the 2008-2009 global financial crisis (GFC) affecting economic development and financial markets (see inter alia, Pasquariello, 2014; Pasquariello \& Zafeiridou 2014; Selmi \& Bouoiyour, 2020). However, the sources of this uncertainty have shifted from the U.S. and European policy reactions to the GFC, to infighting over the U.S. fiscal policy during the period 2011-2013, to Trump's victory in 2016. The U.S. economic policy uncertainty has reached an all-time high since 2016. Large changes in policy uncertainty reflect trade agreements, tariffs, threats, and trade negotiations. Many peaks observed in Figure A1 are likely the reactions to trade policy developments, i.e., the U.S. withdrawal from the Trans-Pacific Partnership January 2017; tariff hikes on U.S. steel and aluminum imports since March 2018 and escalated USA-China trade tensions.

Although uncertainty has distinct causes such as changes in the government and changes in domestic and foreign policies, this study focuses on the escalated trade tensions between the USA and China since 2016. The Trump administration has forged an aggressive anti-China position, accusing it of unfair competition via market-distorting subsidies and forced technology transfers. Accordingly, Trump's imposed unilateral tariffs and decoupled the USA economy from Chinese investment and technology.

Overall, the USA-China stand-off over tariffs is part of Trump's broader protectionist agenda imposing unilateral U.S. tariffs on close allies, including China, to make USA-made products cheaper and to encourage consumers to buy American products, fostering local businesses. Based on USA trade data (U.S. Census Bureau), in 2018, Americans bought $\$ 419$ billion more goods from China than China bought from the USA (the largest value over the last decades). (Thus, there are episodes of large trade surplus of China against the USA.) These data incorporate re-exports of articles into the USA from the American firms in China. In retaliation, China has imposed tariffs on U.S. goods, ${ }^{1}$ ) which has increased costs. Consequently, investor sentiment and confidence are afflicted with uncertainty weighing on business investment. These escalated tensions have affected several sectors, shaking up the consensus on the future of international trade and investment links. Given the recent intensification of the USA-China trade war and prospects of a further widening, it's not surprising that financial markets reacted violently. This paper seeks to analyze the financial implications of the USA-China trade war tensions launched by the Trump administration. More accurately, we address how does this trade war affect the performances of different U.S. companies? To answer this question, we conducted an event study to examine the abnormal return behaviors for distinct industries of the S\&P 500 stock market ${ }^{2}$ ) around the day (on May 13, 2019) of the announcement of tariffs on U.S. imports by China's government. An event study methodology studies changes in stock prices following an unforeseen event. According to modern neoclassical financial theory, the stock price accounts

1) From July 2018 to June 2019, both the U.S. and China tariffs increased sharply (see Figure A2, Appendix).

2) This paper uses the S\&P500 stock market as it is home to the largest publicly traded corporations in the USA. 
for all available information and future expectations. Our paper differentiates between abnormal returns (ARs) and cumulative ARs (CARs) following China's response to U.S. tariffs.

We found that the impact of the USA-China trade war on U.S. sectoral stock prices sector-specific. Technology, industrials, and energy have been most adversely affected. We also found an increase in the short-term systematic risks of the majority of U.S. industries after the escalated USA-China trade war, though with different extent. Our results have relevant implications for investment decisions, portfolio allocation, the pricing of derivative securities, and risk management.

The remainder of this paper is organized as follows. Section II presents our methodology and data. Section III reports the main findings. Section IV discusses the results, whereas Section $\mathrm{V}$ concludes.

\section{Empirical Strategy and Data}

To examine the responses of U.S. industries to the escalated USA-China trade war, we use the market model event study methodology of Dodd and Warner (1983) and Brown and Warner (1985). This methodology has been successfully applied to a large variety of events (Benninga, 2008). A common feature is that the event under consideration is rarely unanticipated. We define day " 0 " as the announcement day of China's tariffs. Then, the estimation and event windows can be determined (see Figure 1). The interval $T_{0}-T_{1}$ is the estimation window that provides the information needed to specify the normal return (i.e., prior to the occurrence of the event). The interval $T_{2}-T_{1}+1$ is the event window, and the interval $T_{3}-T_{2}$ is the post-event window used to investigate the behavior of U.S. sectoral stocks following the event.

The length of the event window often depends on the ability to accurately fix the announcement date. If one can do this precisely, the event window will be less lengthy, and thus, capturing the ARs will be more appropriate. We considered a window of 260 days, consisting of 239 days before the event day and 20 days after the event as well as the event day. There is no consensus on the most appropriate length of the estimation period, but MacKinlay (1997) recommended an estimation period of 260 trading days. For the duration of our paper, we allow for possible overreaction or under-reaction to the tariff announcement on U.S. imports by China, whereby markets tend to correct their mistakes in subsequent periods. 
Figure 1. Event study methodology time frame

Time 0 is the event date

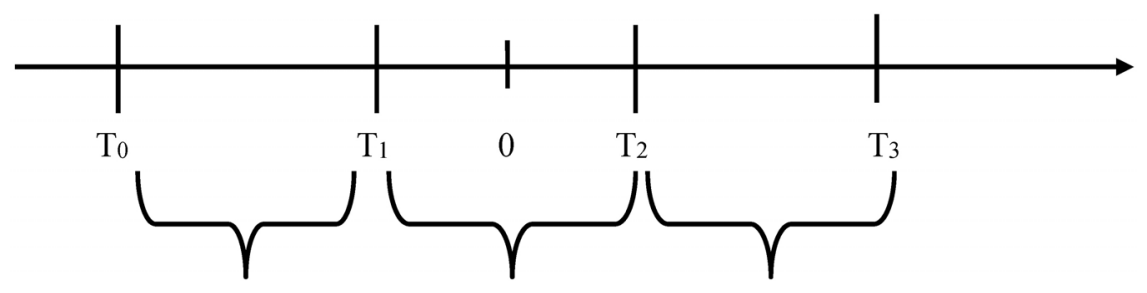

The estimation window The event window The post-event window

Based on the selected return model, event studies consist of applying an event window only (e.g., the market-adjusted model) or an event and an estimation window (e.g., the market model) to the sample data. The market model is the most commonly used in the literature. It predicts normal returns by adjusting daily returns to obtain the ex-post-ARs ${ }^{3}$ ) where adjustment is approximated by the Capital Asset Pricing Model. The ARs are grouped into sectors to determine the sectoral average $(S)$ at time $t,\left(A R S_{t}\right)$ expressed as follows:

$$
A R S_{i t}=1 / n \sum_{j=1}^{n} \ln \left(P_{j t} / P_{j t-1}\right)-E\left(R_{i t}\right)
$$

where $E\left(R_{i t}\right)$ is determined via

$$
E\left(R_{i t}\right)=\beta_{0_{i t}}+\beta_{1_{i t}}\left(\widetilde{r}_{m t_{U S}}-\widetilde{r}_{f t_{U S}}\right)
$$

$P_{j t}$ is the adjusted price of sector $j$ at time $t$. Table 1 reports the number of companies of each sector and data sources. $E\left(R_{i t}\right)$ is the expected return on sector $i$ at time $t, \tilde{r}_{m t_{U S}}$ is the return of each stock sector, and $\tilde{r}_{f t_{U S}}$ corresponds to the 3 month U.S. Treasury Bill used as the risk-free rate for U.S.-based investors.

We estimate the CARs for each sector $i$ during the event window $[\tau 1 ; \tau 2]$ surrounding the event day $\mathrm{t}=0$, where $[\tau 1 ; \tau 2]=\in[-2 ;+2],[-5 ;+5],[-10 ;+10],[-15 ;+15]$, and $[-20 ;+20]$. To determine the ARs, we need information about the sectoral U.S. stock prices. We collected daily time series data from DataStream and Barchart.com, Inc., ${ }^{4)}$ for the period January 2018 to September 2019 (see Table A1, Appendix). The selected industries include financials (banks, insurance, reinsurance, and financial services); energy (oil and gas producers, oil equipment

3) For more details about the event study methodology, see Dodd and Warner (1983) and Brown and Warner (1985).

4) Barchart.com, Inc., is a leading provider of real-time or delayed intraday stock and commodities data. 
and services, distribution, and alternative energy); health care (health care equipment and services, pharmaceuticals, and biotechnology); consumer discretionary (durable goods, apparel, entertainment and leisure, and automobiles); consumer staples (some examples); industrials (construction and materials, and industrial goods and services); technology information (software and computer services, and technology hardware and equipment); telecommunications services (fixed line and mobile telecommunications); materials (chemicals and basic resources); utilities (electricity, gas, and water); aerospace and defense; and real estate.

Each sector index represents a capitalization-weighted portfolio of the largest U.S companies in the sector. As a sensitivity test, we re-conduct the same estimation procedure while incorporating additional control variables (particularly, gold prices and the Chicago Board Options Exchange Volatility Index, i.e., VIX). The data for gold prices and VIX were obtained from the website of the Federal Reserve Bank of St. Louis.

To assess the immediate change in systematic risk, we adjust the CAPM by including an interaction variable. The immediate risk is determined by the average change in risk resulting from an event. A dummy variable $(D V)$, taking the value of 1 on the first day of trading after the announcement of China tariffs on U.S. products (May 13, 2019) and 0, otherwise, is created to describe the instantaneous change in systematic risk. According to Ramiah et al. (2016), the model to be estimated is

$$
\widetilde{r}_{i t}-\widetilde{r}_{f t}=\beta_{i}^{0}+\beta_{i}^{1}\left[\widetilde{r}_{m t}-\widetilde{r}_{f t}\right]+\beta_{i}^{2}\left[\widetilde{r}_{m t}-\widetilde{r}_{f t}\right] * D V+\beta_{i}^{3} D V+\widetilde{\varepsilon}_{i t}
$$

where $\tilde{r}_{i t}$ is sector $i$ 's return at time $t, \tilde{r}_{f t}$ is the risk-free rate at time $t, \tilde{r}_{m t}$ is the return of stocks within each sector at time $t, \beta^{0_{i}}$ is the intercept term, $\beta^{1_{i}}$ is the average short-run systematic risk of each sector, $\beta^{2_{i}}$ is the change in the sector risk, $\beta^{3_{i}}$ is the shift in market returns caused by the event date, and $\tilde{\varepsilon}_{i t}$ is the error term.

\section{Event Study Methodology Findings}

Table 1 reports the ARs and CARs before the announcement of China tariffs on May 13, 2019 ( -239 days), and those after the event day $(+2,+5,+10$, and +20 days). We find that the effect of China tariffs on the U.S. stock market is sector-specific. The trade dispute with China was reputed to benefit U.S. companies; however, our findings indicate the opposite. Some sectors responded more intensely to the escalated rift with China including industrials, energy, technology information, consumer discretionary, and consumer staples. Industrials, for example, experienced an AR of $-1.31 \%$ over 2 days after the announcement of China tariffs 
and $-5.67 \%$ after 20 days. The energy sector experienced an adverse AR of $0.98 \%$ after 2 days of the announcement of tariffs and continued to exhibit negative CARs of $3.46 \%$ after 20 days. Banking and financial services were adversely affected by the tariff announcement $(-0.64 \%$ after 2 days and $1.82 \%$ after 20 days). This is explained by Donald Trump's anti-trade stance, limiting the scope for international banking. The technology sector and communication services were among the most adversely affected sectors $(-1.62 \%$ after 2 days of the announcement date and $-7.43 \%$ after 20 days).

China relies strongly on the U.S. core technology in memory chips, semiconductors, peripherals and software licenses. In fact, as Huawei has expanded, it has become one of the biggest potential customers for U.S. tech firms, purchasing about $\$ 11$ billion of semiconductors and software licenses every year. So not surprisingly, businesses are feeling more anxious navigating the heightened uncertainty of the long-running trade rift with China.

The consumer discretionary sector is adversely influenced by $1.04 \%$ over 2 days after the

Table 1. The sectoral responses of stock prices to the escalated USA-china trade war

\begin{tabular}{|c|c|c|c|c|c|c|c|}
\hline Sectors & $\mathrm{AR}$ & $\begin{array}{c}\text { CAR } \\
(-239)\end{array}$ & CAR2 & CAR5 & CAR10 & CAR15 & CAR20 \\
\hline Consumer discretionary & $\begin{array}{l}-0.76^{* * *} \\
(-4.13)\end{array}$ & $\begin{array}{l}1.24^{* * *} \\
(3.81)\end{array}$ & $\begin{array}{l}-1.04^{* * *} \\
(-4.11)\end{array}$ & $\begin{array}{l}-1.20^{* * *} \\
(-3.86)\end{array}$ & $\begin{array}{l}-1.55^{*} \\
(-1.76)\end{array}$ & $\begin{array}{l}-1.93^{* * *} \\
(-4.49)\end{array}$ & $\begin{array}{l}-2.27^{* * *} \\
(-5.14)\end{array}$ \\
\hline Consumer staples & $\begin{array}{l}-0.31^{* * *} \\
(-3.55)\end{array}$ & $\begin{array}{l}1.49^{* *} \\
(2.38)\end{array}$ & $\begin{array}{l}-0.84^{* *} \\
(-2.17)\end{array}$ & $\begin{array}{c}-0.72^{*} \\
(-1.80)\end{array}$ & $\begin{array}{l}-1.14^{* *} \\
(-2.28)\end{array}$ & $\begin{array}{l}-1.25^{* * *} \\
(-3.40)\end{array}$ & $\begin{array}{l}-1.94^{* *} \\
(-2.51)\end{array}$ \\
\hline Energy & $\begin{array}{l}-1.21^{* *} \\
(-2.52)\end{array}$ & $\begin{array}{l}0.33^{* *} \\
(2.68)\end{array}$ & $\begin{array}{c}-0.98^{*} \\
(-1.76)\end{array}$ & $\begin{array}{c}-0.97^{*} \\
(-1.88)\end{array}$ & $\begin{array}{l}-1.46^{* * *} \\
(-3.38)\end{array}$ & $\begin{array}{l}-1.53^{* *} \\
(-2.79)\end{array}$ & $\begin{array}{c}-3.46^{* * *} \\
(3.56)\end{array}$ \\
\hline Financials & $\begin{array}{l}-1.06^{* * *} \\
(-4.18)\end{array}$ & $\begin{array}{l}0.36^{* * *} \\
(3.28)\end{array}$ & $\begin{array}{c}-0.64 \\
(-0.31)\end{array}$ & $\begin{array}{l}-1.24^{* *} \\
(-2.80)\end{array}$ & $\begin{array}{c}-1.29 \\
(-0.61)\end{array}$ & $\begin{array}{c}-1.46 \\
(-0.84)\end{array}$ & $\begin{array}{l}-0.08^{* *} \\
(-2.41)\end{array}$ \\
\hline Health care & $\begin{array}{l}-0.01^{*} \\
(-1.82)\end{array}$ & $\begin{array}{l}0.41^{* *} \\
(2.24)\end{array}$ & $\begin{array}{c}-0.04^{*} \\
(-1.90)\end{array}$ & $\begin{array}{c}-0.06^{*} \\
(-1.88)\end{array}$ & $\begin{array}{l}-0.03^{* * *} \\
(-3.38)\end{array}$ & $\begin{array}{l}-0.07^{* * *} \\
(-3.41)\end{array}$ & $\begin{array}{l}-0.11^{* *} \\
(-2.72)\end{array}$ \\
\hline Industrials & $\begin{array}{l}-0.84^{* * *} \\
(-3.67)\end{array}$ & $\begin{array}{l}1.21^{* * *} \\
(4.10)\end{array}$ & $\begin{array}{l}-1.31^{* * *} \\
(-4.26)\end{array}$ & $\begin{array}{c}-3.64^{* *} \\
(2.43)\end{array}$ & $\begin{array}{l}-2.89^{* * *} \\
(-3.46)\end{array}$ & $\begin{array}{l}-4.52^{* *} \\
(-2.49)\end{array}$ & $\begin{array}{l}-5.67^{* * *} \\
(-3.36)\end{array}$ \\
\hline Technology & $\begin{array}{l}-1.41^{* *} \\
(-2.83)\end{array}$ & $\begin{array}{l}1.23^{*} \\
(1.92)\end{array}$ & $\begin{array}{l}-1.62^{* * *} \\
(-4.15)\end{array}$ & $\begin{array}{c}-3.15^{*} \\
(-1.82)\end{array}$ & $\begin{array}{l}-4.18^{* *} \\
(-1.91)\end{array}$ & $\begin{array}{l}-5.83^{* *} \\
(-2.59)\end{array}$ & $\begin{array}{c}-7.43^{*} \\
(-1.96)\end{array}$ \\
\hline Materials & $\begin{array}{l}-0.21^{* * *} \\
(-3.15)\end{array}$ & $\begin{array}{l}0.91^{* *} \\
(2.62)\end{array}$ & $\begin{array}{c}-0.14 \\
(-1.52)\end{array}$ & $\begin{array}{l}-0.15^{*} \\
(-1.76)\end{array}$ & $\begin{array}{l}-0.13^{* *} \\
(-2.81)\end{array}$ & $\begin{array}{l}-0.17^{* *} \\
(-2.31)\end{array}$ & $\begin{array}{l}-0.29^{* * *} \\
(-3.46)\end{array}$ \\
\hline Aerospace and defense & $\begin{array}{c}0.01 \\
(1.24)\end{array}$ & $\begin{array}{l}0.43^{* * *} \\
(3.46)\end{array}$ & $\begin{array}{c}0.21^{*} \\
(1.88)\end{array}$ & $\begin{array}{c}0.01^{*} \\
(1.94)\end{array}$ & $\begin{array}{l}-0.03^{* *} \\
(-2.42)\end{array}$ & $\begin{array}{l}-0.08^{* * *} \\
(-3.21)\end{array}$ & $\begin{array}{l}-0.11^{* * *} \\
(-3.61)\end{array}$ \\
\hline Real estate & $\begin{array}{l}-0.11^{* *} \\
(-2.24)\end{array}$ & $\begin{array}{l}0.33^{*} \\
(1.91)\end{array}$ & $\begin{array}{c}0.10^{*} \\
(1.79)\end{array}$ & $\begin{array}{l}-0.02^{* * *} \\
(-3.54)\end{array}$ & $\begin{array}{l}-0.05^{* *} \\
(-2.41)\end{array}$ & $\begin{array}{l}-0.08^{* *} \\
(-2.46)\end{array}$ & $\begin{array}{l}-0.05^{*} \\
(-1.74)\end{array}$ \\
\hline Communication services & $\begin{array}{l}-0.68^{* *} \\
(-2.44)\end{array}$ & $\begin{array}{l}0.43^{* *} \\
(1.99)\end{array}$ & $\begin{array}{l}-0.24^{* * *} \\
(-3.62)\end{array}$ & $\begin{array}{c}-0.31^{*} \\
(-1.90)\end{array}$ & $\begin{array}{l}-0.28^{* * *} \\
(-3.46)\end{array}$ & $\begin{array}{l}-0.35^{* *} \\
(-2.81)\end{array}$ & $\begin{array}{l}-0.41^{* * *} \\
(-3.58)\end{array}$ \\
\hline Utilities & $\begin{array}{l}-0.49^{* * *} \\
(-5.11)\end{array}$ & $\begin{array}{l}0.56^{* * *} \\
(4.18)\end{array}$ & $\begin{array}{l}-0.46^{* *} \\
(-2.34)\end{array}$ & $\begin{array}{c}-0.55^{*} \\
(-1.81)\end{array}$ & $\begin{array}{c}-0.41 \\
(-1.19)\end{array}$ & $\begin{array}{l}-0.51^{* *} \\
(-2.32)\end{array}$ & $\begin{array}{l}-0.48^{* *} \\
(-2.64)\end{array}$ \\
\hline
\end{tabular}

(Notes) AR: Abnormal returns; CAR: Cumulative abnormal returns; *,**, and *** denote statistical significance at the $10 \%, 5 \%$ and $1 \%$ levels, respectively. 
event date and $2.27 \%$ after 20 days. Consumer staples were negatively affected but less so (a CAR of $-1.94 \%$ over 20 days after the announcement day). The utility sector was also adversely influenced after 2 days of the event date, which became stronger after 10-20 days.

Some sectors reacted modestly on the event day with most responses lasting from 2 to 20 trading days. These sectors included real estate, and aerospace and defense. Despite the trade war, these industries should benefit from the Trump administration spending $\$ 1$ trillion to rebuild infrastructure and to spur military spending.

Changes in the short-term systematic risk following the announcement of China tariffs by sector are displayed in Table 2. It is a common practice in finance to calculate changes in systematic risk via Beta. Such results reveal that the U.S. trade war with China has led to a marked increase in systematic risk for most sectors, especially for industrials, energy, technology, financials, communication services, consumer discretionary, consumer staples, and utilities.

Table 2. Changes in short-term systematic risk of U.S. stock sector prices following china's tariff announcements

\begin{tabular}{|c|c|c|c|}
\hline Sectors & $\begin{array}{c}\text { Beta before the } \\
\text { announcement of } \\
\text { China tariffs }\end{array}$ & Immediate risk & $\begin{array}{c}\text { Beta after the } \\
\text { announcement of } \\
\text { China tariffs }\end{array}$ \\
\hline Consumer discretionary & $\begin{array}{c}0.14 * * * \\
(3.55)\end{array}$ & $\begin{array}{c}0.42 * * * \\
(3.82)\end{array}$ & $\begin{array}{c}0.47 * * * \\
(4.52)\end{array}$ \\
\hline Consumer staples & $\begin{array}{c}0.16^{* *} \\
(2.48)\end{array}$ & $\begin{array}{l}0.29 * \\
(1.82)\end{array}$ & $\begin{array}{c}0.33 * * \\
(1.91)\end{array}$ \\
\hline Energy & $\begin{array}{l}0.10^{*} \\
(1.83)\end{array}$ & $\begin{array}{l}0.40 * * \\
(2.76)\end{array}$ & $\begin{array}{l}0.46^{*} \\
(1.79)\end{array}$ \\
\hline Financials & $\begin{array}{c}0.12 * * * \\
(3.56)\end{array}$ & $\begin{array}{c}0.38 * * * \\
(3.61)\end{array}$ & $\begin{array}{c}0.39 * * * \\
(5.07)\end{array}$ \\
\hline Health care & $\begin{array}{c}0.34 \\
(1.15)\end{array}$ & $\begin{array}{c}0.04 * * \\
(2.15)\end{array}$ & $\begin{array}{c}0.05 * * * \\
(3.41)\end{array}$ \\
\hline Industrials & $\begin{array}{c}0.42 \\
(1.36)\end{array}$ & $\begin{array}{l}0.31 * * \\
(2.24)\end{array}$ & $\begin{array}{l}0.46^{* *} \\
(2.51)\end{array}$ \\
\hline Technology & $\begin{array}{c}0.17 * * * \\
(3.17)\end{array}$ & $\begin{array}{c}0.59 * * \\
(2.51)\end{array}$ & $\begin{array}{l}0.72 * \\
(1.84)\end{array}$ \\
\hline Materials & $\begin{array}{c}0.41 \\
(0.58)\end{array}$ & $\begin{array}{c}0.36 \\
(1.24)\end{array}$ & $\begin{array}{l}0.10^{*} \\
(1.88)\end{array}$ \\
\hline Aerospace and defense & $\begin{array}{c}0.64 \\
(1.11)\end{array}$ & $\begin{array}{l}0.02 * * \\
(2.87)\end{array}$ & $\begin{array}{l}0.06^{* *} \\
(2.76)\end{array}$ \\
\hline Real estate & $\begin{array}{c}0.32 \\
(1.19)\end{array}$ & $\begin{array}{c}0.08 * * \\
(2.19)\end{array}$ & $\begin{array}{l}0.11 * \\
(1.76)\end{array}$ \\
\hline Communication services & $\begin{array}{l}0.15^{*} \\
(1.77)\end{array}$ & $\begin{array}{c}0.22 * * * \\
(3.46)\end{array}$ & $\begin{array}{c}0.38 * * * \\
(4.49)\end{array}$ \\
\hline Utilities & $\begin{array}{l}0.09 * \\
(1.83)\end{array}$ & $\begin{array}{c}0.19 * * * \\
(3.71)\end{array}$ & $\begin{array}{l}0.31 * * \\
(2.63)\end{array}$ \\
\hline
\end{tabular}

(Notes) ***, and *** denote statistical significance at the $10 \%, 5 \%$, and $1 \%$ levels, respectively. 
To ascertain the robustness of our results, we conducted tests on each regression model. The Chow test detects structural breaks following the tariff announcement date; the Wald test controls for redundant variables, and $\mathrm{AR}$ and $\mathrm{MA}$ terms are included to account for autocorrelation. Moreover, different GARCH models (symmetric versus asymmetric and linear versus nonlinear) are performed to correct for the $\mathrm{ARCH}$ effects. The results drawn from these tests are available for interested readers upon request.

Furthermore, by accounting for relevant control variables (particularly, the VIX index and gold prices), our results remain fairly robust. Specifically, we consistently find that responses of U.S. stock prices to the trade war vary across industries either for the event day CARs or for the $[-20 ;+20]$ event window CARs. Some sectors reacted negatively and more strongly than other sectors. The most harmed sectors are technology, industrials, financials, communication services, consumer discretionary, consumer staples, and utilities. For investors who choose to use the hedging characteristics of sectoral stock returns to protect against rising uncertainty over the USA-China trade war, it is important to ascertain if the impact of the current trade war on sectoral stock prices is consistent over different window events (before the announcement of tariffs, immediately, and after announcement date).

Figure 2. The cumulative abnormal returns of the sectoral U.S. stock prices in response to the Announcement of china tariffs: $[-20 ;+20]$ event window
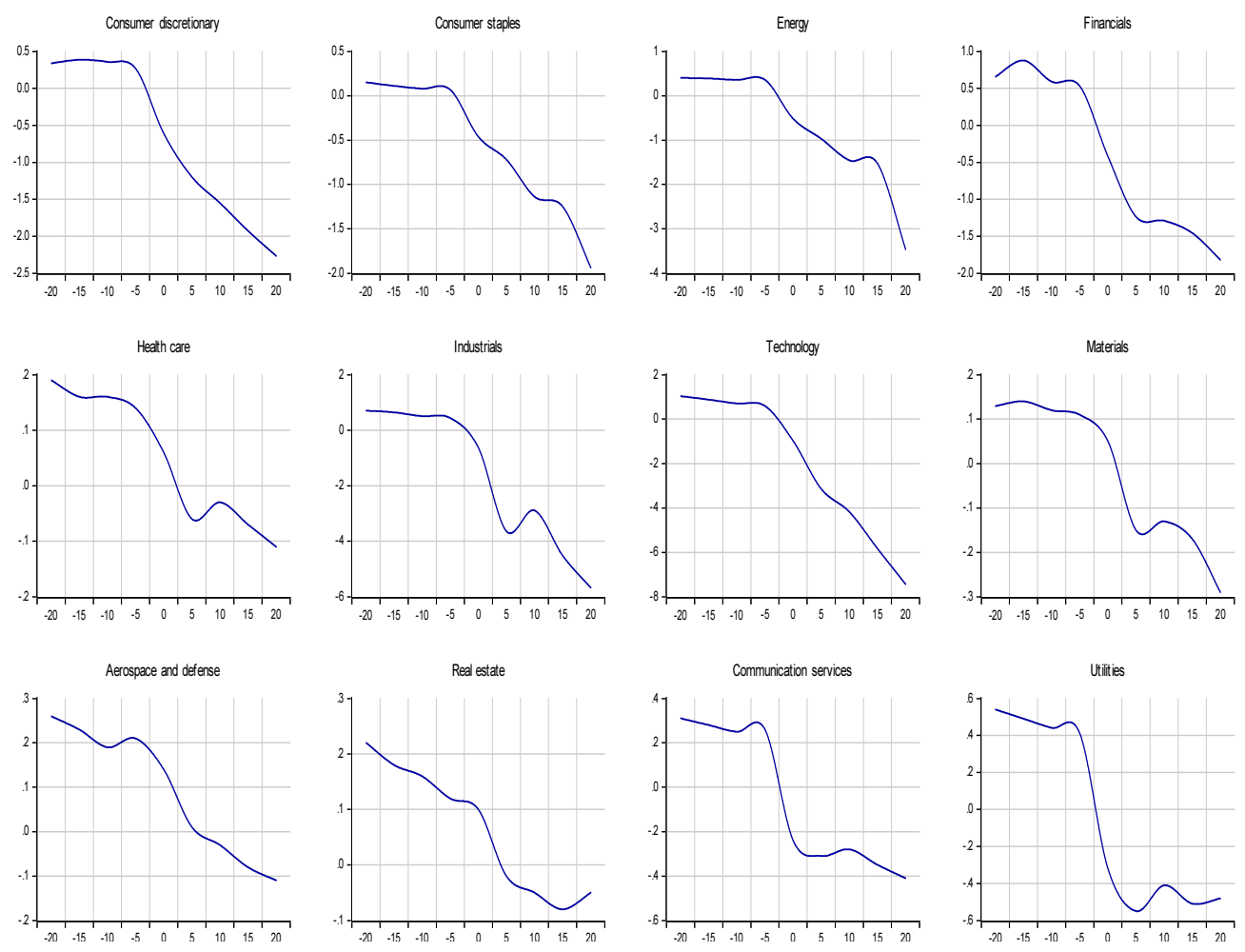


\section{Discussion of Results}

Our results indicate that escalated trade tensions between the USA and China have varying effects on stock market prices. More particularly, the adverse responses of technology, industrials, and energy sectors were stronger than financials, consumer discretionary and staples, health care, real estate, aerospace and defense, and utilities. The technology sector has been seriously affected. This outcome is not surprising, given that Chinese companies buy high-tech inputs from the USA. But current developments in the trade war have questioned this link. China might move to safe and friendly countries including South Korea, Russia, and Canada. The Chinese also encourage domestic companies to produce many inputs at home, even with a greater cost. Moreover, tariffs on energy for which China has fewer competitors makes it difficult for the USA to switch. Some industries especially consumer staples like food and beverages are less influenced by the trade war as their revenues are more domestically focused.

But the negative reaction of this sector can be attributed to the impact of trade tensions on agriculture. China is the fourth biggest agricultural export market for the USA. Based on the statistics of the Office of the U.S. Trade Representative, the global exports of agricultural products to China totaled $\$ 9.3$ billion in 2018. Moreover, China has been and continues to be the largest importing country of U.S. soybeans with $\$ 3.2$ billion in 2018. Other significant agricultural products exported to China include cotton (\$924 million), hides and skins ( $\$ 607$ million), pork products (\$571 million), and coarse grains (\$530 million).

Our article'outcomes are consistent with the factthat bad news often has more pronounced effects than good information news (Williams, 2009). In fact, increased uncertainty due to the trade war between the two economic superpowers would reduce the incentive to invest, and investors will become more pessimistic reacting to bad news.

Another major consequence is that we noticed a marked rise in the short-term systematic risks of all U.S. stock market prices after the escalated USA-China trade war, though with varying extent. This highlights that uncertainty persists and even increases. Our findings provide crucial information to agents concerning the sectors of the U.S. stock market in which they do not need to invest during high uncertainty to minimize risk. Particularly, an effective investment strategy could avoid the negative and pronounced reactions of industrials, energy, technology information, and the insignificant or relatively moderate responses of health care, real estate, and aerospace and defense.

Our results may be very useful for portfolio construction and diversification, as variant sensitivities to China tariffs have been discovered. Such precise analysis of the effects of tariffs is useful for two reasons. First, financial risk management necessitates an effective analysis of responses to uncertainty as a requisite input to risk management for financial institutions (Gil-Alana et al., 2014; Yaya et al., 2015). Second, stock price changes due to increased 
uncertainty can have large repercussions on the economy via its impact on real economic activity and public confidence. Certainly, estimates of market reactions during uncertainty can be viewed as an appropriate measure of the vulnerability of financial markets and the economy and could enable policymakers to design alternative policy options for deepening trade tensions.

\section{Conclusions}

The trade tensions between the USA and China have been and continue to be a topic of contention. Our study performed an event study methodology to investigate the reactions of the sectoral U.S. stock prices to China tariffs. Our results clearly show the vulnerability of U.S. sectoral stock prices to trade uncertainty. Generally, the initial effects of trade tensions appear more significant than had been expected, reflecting the uncertainty shock. The sentiment and confidence of investors are impacted by heightened uncertainty. However, our results should be interpreted with caution as a lack of clarity surrounds USA-China trade negotiations. Some observers have indicated that the last "phase one" trade deal signed on January 2020 would leave in place most of the trade war tariffs that continue to burden both consumers and producers The world looks for trade war deal in the hope that it will mitigate heightened uncertainty. So long as there is no resolution in the showdown between the USA and China, it will continue to be a drag on the global economy, which is not in great shape.

As the long-term consequences remain conditional on progress in any USA-China trade talks and as concerns mount that the resulting tariff war could tip the global economy into recession, more research is required to better understand the complex USA-China trade negotiations by (1) determining the mechanics of the USA-China business negotiations including the hidden workings of the USA-China trade negotiations, (2) understanding the contributing factors, (3) understanding the outcomes, and (4) their implications for the global markets and particularly how to effectively safeguard against the heightened uncertainty.

\section{References}

Backer, S., Bloom, N., \& Davis, S., (2019). The extraordinary rise in trade policy uncertainty. Vox CEPR Policy Portal, Available at https://voxeu.org/article/extraordinary-rise-trade-policy-uncertainty Benninga, S. (2008). Financial modeling (3rd edition). Boston, MA: MIT Press.

Brown, S. J., \& Warner, J. B. (1985). Using daily stock returns: The case of event studies. Journal of Financial Economics, 14(1), 3-31.

Dodd, P., \& Warner, J. B. (1983). On corporate governance: A study of proxy contests. Journal of Financial 
Economics, 11(1/4), 401-438.

Gil-Alana, L. A., Shittu, O. I., \& Yaya, O. S. (2014). On the persistence and volatility in European: American and Asian stocks bull and bear markets. Journal of International Money and Finance,, 40(C), 149-162.

Mackinlay, C. (1997). Event studies in finance and economics. Journal of Economic Literature, 35, 13-39.

Pasquariello, P., \& Zafeiridou, C. (2014). Political uncertainty and financial market quality. University of Michigan Working Paper.

Pham, H. N. A., Ramiah, V., Moosa, I., Huynh, T., \& Pham, N. (2018). The financial effects of Trumpism. Economic Modelling, 74, 264-274.

Ramiah, V., Pham, H. N. A., \& Moosa, I. (2016). The sectoral effects of Brexit on the British economy: Early evidence from the reaction of the stock market. Applied Economics, 49, 2508-2514.

Selmi, R., \& Bouoiyour, J. (2020). The financial costs of political uncertainty: Evidence from the 2016 U.S. presidential elections. Scottish Journal of Political Economy, 67(2), 166-185.

Williams, C. D. (2009). Asymmetric responses to earnings news: A case of ambiguity. Working Paper, University of North Carolina.

Yaya, O. S., Gil-Alana, L. A., \& Shittu, O. I. (2015). Fractional integration and asymmetric volatility in European, American and Asian bull and bear markets: Application to high frequency stock data. International Journal of Finance \& Economics, 20(3), 276-290. 


\section{Appendix}

Figure A1. The evolution of the U.S. economic policy uncertainty from 1985 to 2019

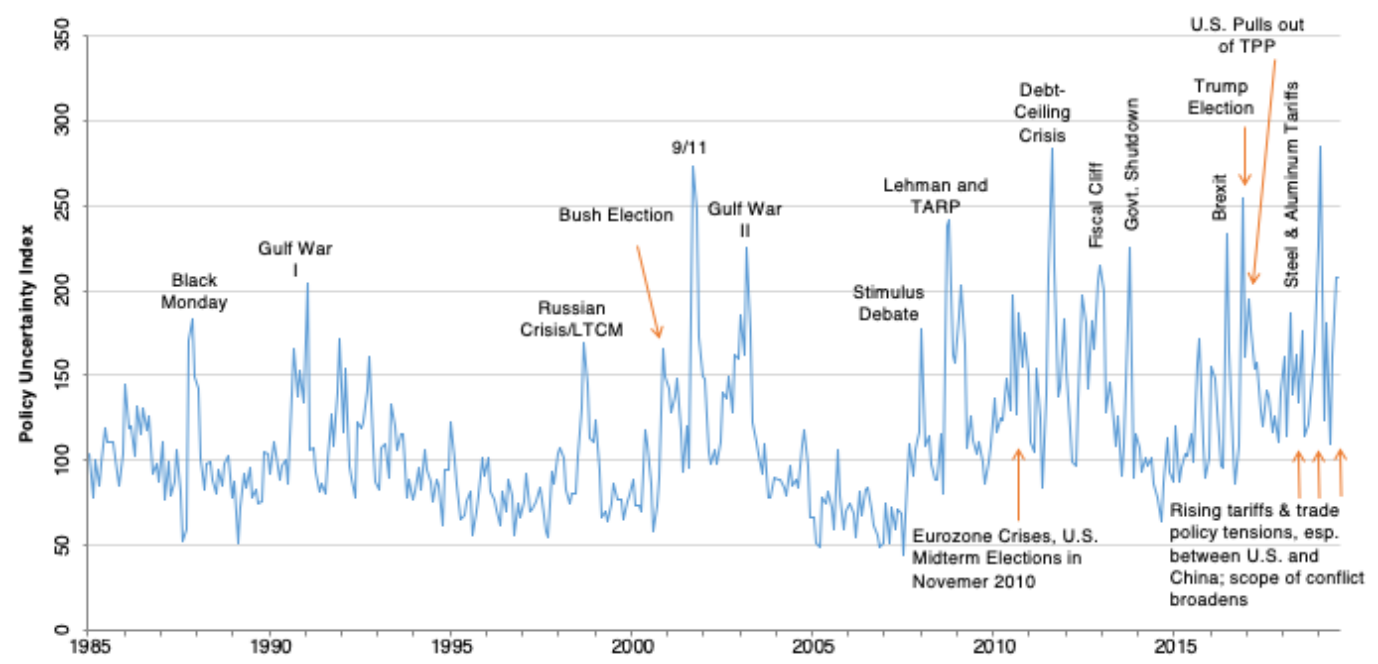

(Source) Backer et al. (2019); https://voxeu.org/article/extraordinary-rise-trade-policy-uncertainty

Figure A2. Graphical summary of U.S. and china tariffs

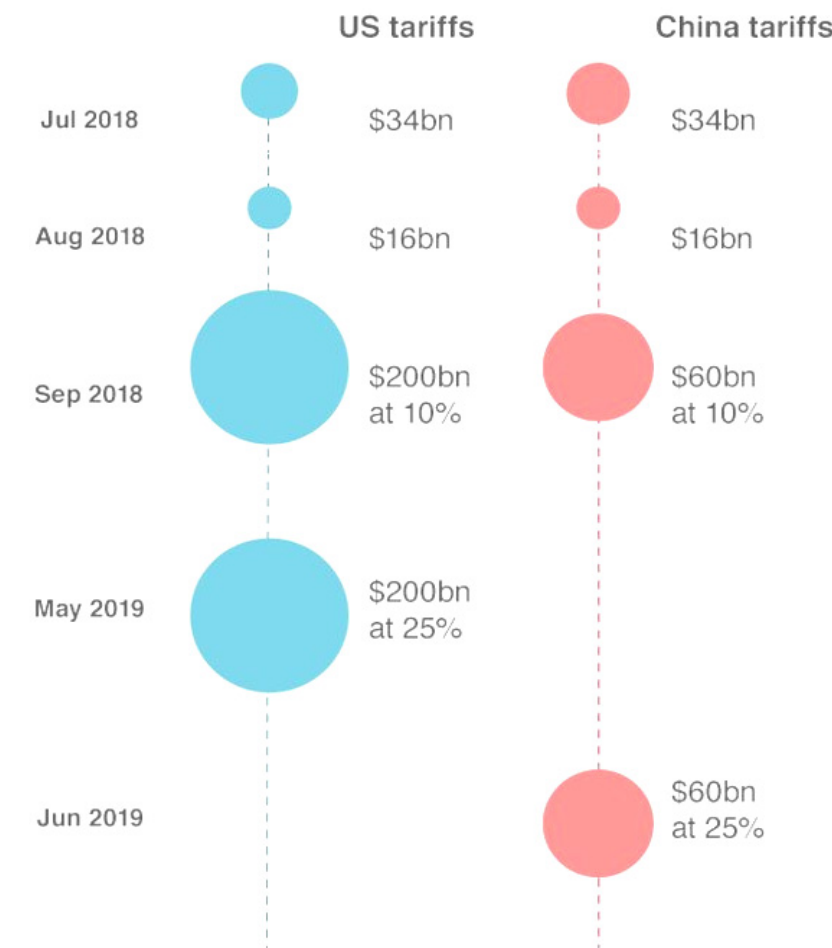

(Source) Peterson Institute for International Economics, Straits Times Graphics. 
Table A1. Key dates in the USA-china trade war

\begin{tabular}{|c|c|}
\hline Dates & U.S. action \\
\hline March 22, 2018 & $\begin{array}{l}\text { Donald Trump signed a memorandum } \\
\text { imposing tariffs on Chinese products } \\
\text { ( } 25 \% \text { on steel imports and } 10 \% \text { on } \\
\text { aluminum imports). }\end{array}$ \\
\hline
\end{tabular}

April 2, 2018

China imposes tariffs ranging between $15 \%$ and $25 \%$ on 128 U.S. products.

May 3, 2018

China action

Simultaneous action

April 16, 2018

The U.S. Department of Commerce noticed that Chinese Telecom ZTE violated U.S. sanctions, and decided to ban U.S. companies from doing business with it.

June 16, 2018

August 3, 2018

September 12, 2018

China revises its tariffs list and includes a $25 \%$ tariffs on 545 products, starting July 6, 2018.

China announces the second round of tariffs on U.S. products.

USA and China engage in trade talks. They end with no sign of resolution.

The USA invites China to restart trade negotiations.

The USA and China implement

September 24, 2018 the third round of tariffs.

May 10, 2019

The USA increases tariffs from $10 \%$ to $25 \%$ on Chinese products.

May 13, 2019

China announces an increase in tariffs on U.S. products. 
Table A2. The number of companies of each the U.S. stock sector

\begin{tabular}{|c|c|c|}
\hline Sectors & $\begin{array}{l}\text { Number of } \\
\text { companies }\end{array}$ & Sources \\
\hline Consumer discretionary & 64 & https://www.barchart.com/stocks/indices/sp-sector/consumer-discretionary \\
\hline Consumer staples & 33 & https://www.barchart.com/stocks/indices/sp-sector/consumer-staples \\
\hline Energy & 29 & https://www.barchart.com/stocks/indices/sp-sector/energies \\
\hline Financials & 68 & https://www.barchart.com/stocks/indices/sp-sector/financials \\
\hline Health care & 61 & https://www.barchart.com/stocks/indices/sp-sector/health-care \\
\hline Industrials & 70 & https://www.barchart.com/stocks/indices/sp-sector/industrials \\
\hline Technology & 68 & https://www.barchart.com/stocks/indices/sp-sector/information-technology \\
\hline Materials & 25 & https://www.barchart.com/stocks/indices/sp-sector/materials \\
\hline Aerospace and defense & 13 & http://investsnips.com/aerospace-defense-stocks-in-the-sp-500-index/ \\
\hline Real estate & 32 & https://www.barchart.com/stocks/indices/sp-sector/real-estate \\
\hline Telecommunication services & 24 & https://www.barchart.com/stocks/indices/sp-sector/telecom-services \\
\hline Utilities & 28 & https://www.barchart.com/stocks/indices/sp-sector/utilities \\
\hline
\end{tabular}

(Source) Barchart.com, Inc. 